\title{
Media aesthetic component of communication and its manifestation in infographic content
}

\section{Svetlana Simakova ${ }^{1}$}

\section{Abstract}

The goal of the present study is to demonstrate the media-aesthetic potential of infographic messages on particular cases. This can be done due to an integrated approach to the analysis of the visual content of media content. That indicates the case study method implementation as well as description and generalization. The theoretical basis of the research is represented by scientific studies of various directions. That includes the history of media and visual media culture; features of the concepts of media culture and media language, media aesthetics; infographics as a tool of media language. The empirical basis of the study is journalistic materials containing infographic content of such publications as by RIA Novosti (ria.ru), TASS (tass.ru). The examples of visual image implementation in the transmission of information - media content containing infographics - are given and analyzed. Considering media aesthetics as the formation of a sensory perception of the proposed media content, the author turns to the philosophical and aesthetic foundations of visual practices in the media and post-humanistic trends in journalism. As a result of the analysis of the theoretical and practical basis of the research, the author comes to the conclusion that today the role of the media aesthetic component of messages is most relevant. And infographics, as the connecting link of language and consciousness, is its most striking tool.

\section{Keywords}

Media Aesthetics; Infographics; Infographic Content; Aesthetic Turn; Media Aesthetic Component 


\section{Componente estético da mídia na comunicação e sua manifestação no conteúdo infográfico}

\section{Svetlana Simakova ${ }^{1}$}

\section{Resumo}

O objetivo do presente estudo é demonstrar o potencial estético-midiático de mensagens de infográficos em casos particulares. Isso pode ser feito devido a uma abordagem integrada à análise do teor visual do conteúdo da mídia. Isso indica a implementação do método de estudo de caso, bem como a descrição e generalização. A base teórica da pesquisa é representada por estudos científicos de várias direções. Isso inclui a história da mídia e da cultura visual da mídia; características dos conceitos de cultura e linguagem da mídia, estética da mídia; infográficos como uma ferramenta da linguagem de mídia. A base empírica do estudo são materiais jornalísticos que contém conteúdo infográfico de publicações como RIA Novosti (ria.ru), TASS (tass.ru). Os exemplos de implementação de imagens visuais na transmissão de informações - conteúdo de mídia contendo infográficos - são dados e analisados. Considerando a estética da mídia como a formação de uma percepção sensorial do conteúdo proposto, o autor se volta para os fundamentos filosóficos e estéticos das práticas visuais na mídia e tendências pós-humanísticas no jornalismo. Como resultado da análise da base teórica e prática da pesquisa, o autor conclui que hoje o papel do componente estético da mídia nas mensagens é mais relevante. E os infográficos, como elo de ligação entre linguagem e consciência, são sua ferramenta mais marcante.

\section{Palavras-chave}

Estética da Mídia; Infográficos; Conteúdo Infográfico; Mudança Estética; Componente Estético da Mídia 
Among the main trends that reflect the transformation in mass communication today, there is a trend of the media visualization, which is under analyses in the present research. "Aesthetic turn" is becoming ever more relevant along with the "visual turn". Consequently, the role of the media aesthetic component of communication is becoming dominant, which makes it a prior field of media communicators' research. Media aesthetics - the aesthetics of media - which is understood in the present study as the formation of sensory perception of the proposed media content.

In this connection, the purpose of the present research (is supported by the Russian Science Foundation, 18-18-00oo7) can be formulated as follows - to demonstrate the media aesthetic potential of infographic messages implimenting particular cases.

The achievement of this goal was carried out both through a consideration of the philosophical and aesthetic foundations of visual practices in the media of communication, and in the context of posthumanistic trends in journalism.

The presented study is based on a large amount of scientific literature. Its analysis allows to focus on such areas as: the history of media and visual media culture; features of the concepts of media culture and media language, media aesthetics; infographics as a tool of media language.

The research of McLuhan is the on the top. The studies Gutenberg Galaxy: The Making of Typographic Man (MCLUHAN, 2004) and Understanding Media: the Extensions of Man (MCLUHAN, 2003) have long remained important and relevant in the study of the impact of media and online media on society, in the study of diverse the influence of culture and philosophy on the development of media. The book Optical Media, a lecture course by the German literary historian, electronic media by theorist Kittler (KITTLER, 2009) possesses a big impact. The scientist reveals the evolution of the media, taking as a basis their dispersive field, which is optics. Kittler notes that optical media proceed their own evolutionary path (starting from the ancient period). The author produces the historical archeology of media platforms (media technologies), tracing it from antiquity to the advent of the computer., The article Deus Ex Machina: The Human during the Expansion of the Mechanical and the Electronic by of Zagidullina is of interest as part of the present study. The author claims that throughout the history of mankind such qualities as mechanical, sacred, and human are closely intertwined. Emphasizes that with the cult of everything mechanical, the genre of techno utopia is eroded. As an example, the researcher draws attention to such a technical breakthrough as the invention of the camera and the mass distribution of photographing, which included not artists, but specialists in technology and practical 
chemistry of reagents in the field of visual arts (ZAGIDULLINA, 2018, p. 441).

Considering the concepts of media culture, media language and media aesthetics, the study Digital culture: the horizons of artificial life raises the issue of cultural production in the paradigm setting of digital culture, which is directly related to the topic of the present study and the current interest in aesthetic turn in the media (GALKIN, 2005, 2013). The study by Pierre Bourdieu describes the production of symbolic products (BOURDIEU,1993, 2005). In the framework of the present study, it seems important to denote the opinion of Mitchell - the author of the term pictorial turn - a picture is not a text, and it cannot be analyzed as a text, that is, semiotic and linguistic methods are not suitable for the case (MITCHELL, 2015). A similar opinion is shared by Buyakova. The researcher postulates "visual experience or visual literacy cannot be fully explained within the framework of the textual model" (BUYAKOVA, 2013, p. 228). The studies of visual culture and its individual aspects are discussed by Gabova (2017), Kazarina (2018), Kintsapsa (2016). Kintsaps states that "modern culture is undergoing some kind of Renaissance", and "sight, vision and visualization are provided with more attention than other abilities" (KINTSANS, 2016, p. 30). Kazarina notes that the process of forming a culture of visualization is not yet completed and complements the typology of Bezzubova, including the fourth stage - "the first decade of the XXI century is the step of a visual turn" (KAZARINA, 2018, p. 119). The study Vision Machine is devoted to the issue of media culture (VIRILLO, 2004). The author considers media culture through the perspective of the evolution of perceptual practices (practices of perception). According to Virillo, through these practices, a person enters into communication at different levels, which is relevant to the concept of media, since it is the media that are the means of transmitting the message (the means of communication). Manovich raises the question of a scientifically-systematic understanding of the theory of new media. In the book Language of Nero Media, the author examines new digital media through as an accumulated experience of visual culture and which have already become traditional forms of media culture. Thus, Manovich focuses on the fact that a new visual modern media language has appeared (MANOVICH, 2018). Among the studies devoted to media aesthetics it is also important to single out such researches as Sight Sound Motion: Applied Media Aesthetics, Sixth Edition by Zettl (2011), The language of new media by Manovich (2001), article representative of the Russian scientific school of Zagidullina such as Key Features of Media Aesthetics: Mental and Linguistic Transformations (2016).

In the framework of thepresent study, the most interesting are the works that highlight the manifestations of the trend of information visualization in modern 
media and mass media. Those are researches by Gorbacheva (2015), Svitich (2016), Tulupov (2015) and Shevchenko (2014).

The development of technology is supposed by the present study to be one of the most important factors in the emergence and development of new types of visualization. Gorbachev adheres to the same opinion. The researcher states that today there is a reduction in the cost of photo and video equipment, and there is no shortage in the market segment, which allows everyone to possess means of making pictures and video, create photo and video products and, what is important to implement it without additional processing. The researcher's observation is intriguing. It states that the development of modern means of communication leads to the emergence of information greed. That is the simultaneous availability of different information makes a person crave to get it all and as quickly as possible. The author is sure that visual communication indulges in informational greed, providing instead of reading a description, a-quick-look-at-the-picture approach (GORBACHOVA, 2015, p. 134135). The author of one of the common typologies of visual content in the media is Shevchenko (2014). The author's typology is implemented on the basis of the print media (as an example). Svitich (2016, p.3) believes that for the print media it is enough to distinguish three groups of illustration - photos, graphics and infographics. The presentstudy denotes that both of these typologies require adjustment and refinement, since subtypes can be distinguished within each group. For example, a photo is a photo note, a photo portrait, a photo report (TULUPOV, 2015, p. 140). The typology proposed by Shevchenko suggests a more extensive list of types of visualization of media content due to the inclusion of many subspecies of visual messages. However, it also requires to be improved, to be supplemented with those types and forms of visualization that appear within the online technologies development.

The present study considers visual formats in the media a tool to transmit information in a concise form (this is especially true for subject areas that are difficult to understand in verbal representations), to cut off unnecessary information, and to retain media attention for a long time. The author of the present study agrees with Shevchenko, who claims that "one can visualize a certain territory, a portrait of a person, manual for a TV settings, a plane crash, the political situation, sports achievements, a cooking recipe - absolutely all kind of data" (SHEVCHENKO, 2014). It is another thing that different phenomena and subject areas require different forms of visualization. In one case, a photo essay would be the most appropriate, in the other one explanatory infographics is the most suitable, in the third, a bright color accent fits best. Serious detailed analytical content often requires combination of different types 
of visual content. Infographics is gaining more and more popularity. Infographics is a dynamically developing visualization tool that, several years ago, went through its peak of popularity in the media sphere. Infographics is considered in the present study as a combination of text and images created implementing design graphics in order to translate any meanings. Infographics as a product of the corporate work of a designer and a journalist is a "valuable social currency", aesthetically attractive, information-intensive, and catchy. Modern infographics can be presented not only online in the traditional static form, but also in an interactive format that allows a consumer to control the display of data.

Considering the topic of infographics and infographic content, it is necessary to single out the studies of such authors as Frolova (2015) and Zitzer (2014). Especially worth noting the authors of PhD thesis such as Cairo (2013) and Laptev (2018); Sergey Ostrikov (2014a, 2014b) and Laikova (2016). It should be noted that the topic of infographics and infographic content in the media is devoted to many scientific studies of the author of the present research (SIMAKOVA, 2019a, 2019b).

It should be noted that today there are a large number of definitions of the term "infographics". And this only emphasizes the ambiguity of the situation with the terminological base. Russian art historians Ostrikov (2014a) and Laptev (2018) understand infographics as a special method of presenting information through verbal and graphic communication media, the main task of which is to effectively transmit data. According to Ostrikov, "infographics [...], in contrast to scientific visualization, are more spare of choosing presentation forms, it allows to simultaneously perceive, evaluate, and compare large amounts of abstract data" (OSTRIKOV, 2014b, p. 24). The famous Spanish infographic designer, Professor Cairo, considers infographics as a "functional art." He emphasizes its applied purpose, which is to structure information for a comfortable reading (CAIRO, 2013). Following them, other contemporary researchers believe that the generally accepted term infographics cannot incorporate all modern technologies for presenting information due to the broadest possibilities of media content tools. They suggest introducing a new term. That is media infographics. Laikova (2015) understands media infographics as a kind of "synthetic form of organizing media content", which is a special creolized text based on a combination of verbal and non-verbal components. The study Information Visualization and Infographics by Kroshneva and Malenova (2018) describes media infographics and its functions quite interestingly and complete. In the article The Philosophical and Aesthetic Foundations of Visual Practices in Fournalism, the analysis of infographics is performed on two bases: infographics is an illustration of media 
content and infographics is a media language (SIMAKOVA, 2019b). The author also considers infographics as a way of visualizing media content as the most prominent representative of the media content of the post-humanism era. The concept is Covered in depth in the article Infographics in the Context of Post-humanistic Trends in Fournalism. The embodiment of the infographics media-aesthetic potential, at the present stage in the life of mankind - the stage of post-humanism - is revealed with the cases (SIMAKOVA, 2019a).

Audiences need a vibrant, informative, engaging format, and infographics is a compelling response to an audience request. But today's infographics should be significantly differ from what could have been provided to the audience a few years ago. In order to combine a large amount of information within one media content unit, the author requires enormous erudition and rich background knowledge, empirical and emotional experience, culture and aesthetic taste. These characteristics should have been possessed by a publicist at the dawn of the advent of journalism. The tradition is still relevant. According to Kroychik, "the impact of the text on the audience is largely determined by the author's desire to aesthetically design the message, make it attractive, understandable and easy to read when transmitted through mass communication channels" (KROYCHIK, 2012, p. 101). It must be remembered that "a text is an expression of consciousness reflecting something" (BAKHTIN, 1986, p. 311). And in the opinion of Tonkikh and Yaretsky, the language bears in itself the peculiarities of the mentality of the people as "the totality of conscious and unconscious factors" (TONKIH; YARETSKY, 1999, p.103). According to Erofeeva and Filshina, the experience of numerous generations is embodied in the language and the main cultural codes are set (EROFEEVA; FILSHINA, 2017). All this can be observed in modern infographics.

Considering infographics as a media language, the present study denotes that it (infographics) allows to present the result of these actions visually, expressively, convincingly, therefore, the issue of the aesthetic component of this type of media text deserves special attention.

The reasons for the demand and effectiveness of infographics are explained primarily by its generic property: it is able to attract attention to big data that is visualized, systematized and personalized. All these determine the journalism of the media text type. Infographics possesses the ability to present the place of data in the recipient's mental space, allows to define infographics as the most personalized product of design creativity. Personalization at the same time manifests itself at all levels of the media text. These are the principles of information selection, a system of verbal means and design. 
No less important is the fact that practically inexhaustible intellectual and artistic possibilities are so necessary and in demand precisely in journalistic discourse. Accordingly, the potential of infographics can be revealed only in journalism and more widely in the communication media, since in the entire information and communication space it possesses both the right and the tools to interpret facts, to provide them with emotional coloring, different interpretations, perceptions, etc. (JACOBSON, 2012).

The popularity of infographics in modern content [1] proves that this is one of most effective information tools that refutes the prevailing thesis that graphics is necessary only by non-thinking readers, and that quantitative statistical information is "boring" (NIKULOVA; PODOBNYKH, 2010). The case study method reveals the idea by analyzing particular media content units in detail.

As an example, Mendeleev - Peter the Great ... and other flights that may appear in the Russian sky is considered from the point of view of the infographic content analyses [2] of the site TASS. Infographics [3].

Not only the visual presentation of digital material, but also its emotional aspect: how clearly, originally, artistically and expressive the author explains the events are analyzed.

This content is a response to one of the topics actively discussed at the time in Russia. It deals with the renaming of airports. It contains static and moving elements. Many of the elements are tailored to the airports concepts: flying airplanes, information desks, luggage carts. That gives the effect of constant movement, which corresponds to the atmosphere of the airport. That is constant dynamics. Infographics is presented in quite bright colors. The main are white, red, blue and orange. These bright, sunny, positive colors are very pleasant for perception. The greatest effect is achieved through technical means, in particular, due to moving illustrations that carry a deep meaning. Thus, the infographic language allowed to create a unique media production, which is, firstly, logical at the level of composition, secondly, interesting - at the level of plot and means of expression, and, thirdly, expressive - at the level of design.

The sufficiently revealed above properties of infographics - the ability to attract attention to big data through visualization, systematization, and personalization are manifested in the media unit Three Charts about Anna Akhmatova [4]. The authors have chosen three aspects, the most vivid, from their point of view, characterizing the poetry writing. Firstly, it is the Ambiance of the writing (how the mood of poetry changed throughout he poet's life, analyzed through texts and average of floruit). Secondly, The Language of Anna Akhmatova poetry, described by the vocabulary usage 
statistics of two main poems Rekviem (Requiem) and Poema bez geroiya (Poem without a hero). Big data is presented as interactive graphic images in which a journalistic image is created by a variety of means (verbal, iconic), but it is the design, and, above all, the color scheme that provide emotional contact between the addresser and the addressee. The infographics (At Great Cost - At Great Blood) [5] devoted to the topic of donation is indicative from this point of view: for the presentation of information, the authors have chosen sketches in a schematically primitive style with a dominance of red (semantics of blood and joy), black (semantics of evil and death) and gold (semantics of life and its value, as well as plasma) colors. This design is determined by functional tasks: as easily and as clearly as possible to provide answers to questions - Why donate blood? How many people in Russia donate blood? How much blood is required? Why is donated blood required all the time? How often do they donate blood in Russia? Why do I need to donate blood for free? What gives an active donation? Dialogue as the most important quality of a media text is presented at all levels. On the verbal level: it is the dominance of a question-answer format; on the visual - it is symbolic colors establishment in the format of a confidential conversation, schematic sketches and graphs make information accessible and emotionally expressive.

The infographic of Pozhar $v$ sobore Parizhskoiy Bogomateri (Fire in the NotreDame de Paris) is released very quickly (in a few hours)[6]. an infographic includes a dramatic screensaver in the form of black and red graphics depicting a fire and two satellite photos, where the location of the event and the lost parts of the building are indicated in red. Taking into account the speed, it is difficult to demand a complete imagery of a multicode text, but from the point of view of style, the design tools have been chosen absolutely precisely: against the background of neutral gray-green satellite photos, an exciting and dramatic scarlet color creates the effect intended by the authors. The simplicity of artistic techniques in this case is very appropriate in the view of the dramatic nature of the situation. It creates an image based on a feeling of deep empathy, which is achieved through a fundamental rejection of pathos and exaggerated gestures.

The infographics considered in the present study allows to characterize the new principles of communication based on the active participation of the addressee in the process of perceiving the media text, and hence the formation of a media image based on the information received. Note that when creating an infographic unit, both the designer and the reporter work with facts, turning them into a media image. Thus, realizing the media aesthetic potential of infographic content.

Summarizing the theoretical and practical experience (the study is supported 
by the RSF grant, project No. 18-18-00007), it is important to note the following: the language of infographics is factual, informative, and correctly visualized. At the same time, both substantive and design principles of systematization, structuring and presentation of information are equally important. Infographics is the connection of language and consciousness. Consequently, there are great prospects for the language of infographics, as a kind of media language. There is a change in the value basis, including in media content, towards technologicalization in the era of the dominance of information culture, global processes of informatization and computerization of all spheres of public life and, as a result, visualization and robotization of mass communication. The aesthetics of the media, which does not exclude the formation of humanistic traditions - attention to a Man - is combined with a post-humanistic non-emotional. And infographics is the most striking media tool for transforming the processes of perception of reality - post-humanism. Therefore, when creating an infographic message, both substantive and design principles of systematization, structuring and presentation of information are equally important. It is so that both are viewed from ideological persepctive - the idea that the author wants to express - and from an aesthetic point of view - how accurate and harmonious the replicated artistic image is.

\section{Notes}

[1] Disponível em: <https://infographics.tass.ru/, https://www.vedomosti.ru/, http://www.aif. ru/infographic $>$. Acesso em: 10 abr. 2020.

[2] Disponível em: <https://velikie-imena.tass.ru>. Acesso em: 10 abr. 2020.

[3] Disponível em: https://infographics.tass.ru>. Acesso em: 10 abr. 2020.

[4] Disponível em: $<$ https://tass.ru/spec/ahmatova $>$. Acesso em: 10 abr. 2020.

[5] Disponível em: <https://donor-krovi.tass.ru/>. Acesso em: 10 abr. 2020.

[6] Disponível em: <https://ria.ru/20190416/1552736364.html>. Acesso em: 10 abr. 2020.

\section{References}

BAKHTIN M. Literary and Critical Articles. Moscou: Art. Lit, 1986.

BOURDIEU P. Literary Field. Translation from French with Abbreviation. Social space: fields and practice: digest of articles, 2005, Online. Disponível em: $<$ https:// gtmarket.ru/laboratory/expertize/3042>. Acesso em: 10 abr. 2020. 
BOURDIEU, P. The Field of Cultural Production. Questions of Sociology, n.2, Online, 1993. Disponível em: <http://bourdieu.name/book/export/html/51>. Acesso em: 10 abr. 2020.

BUYAKOVA, YU. Vizual'nyy Povorot v Kul'ture, Modernizatsiya Kul'tury: idei i paradigmy kul'turnykh izmeneniy. Anais... TEEM'18: Proceedings of the Sixth International Conference on Technological Ecosystems for Enhancing Multiculturality. Nova York, 2018.

Disponível em: < https://dl.acm.org/doi/abs/10.1145/3284179.3284277 >. Acesso em: 10 abr. 2020.

CAIRO, A. The Functional Art: An Introduction to Information Graphics and Visualization. Berkeley: New Riders, 2013.

EROFEEVA, I., FILSHINA, O. National Stereotypes as a Topoi of a Media Text: Relevance of Media Archeology. Humanitarian vector, n.5, Online, 2017, Disponível em: $<$ https://cyberleninka.ru/article/n/natsionalnye-stereotipy-kak-toposmediateksta-aktualnost-mediaarheologii>. Acesso em: 10 abr. 2020.

FROLOVA, M. New Possibilities of Infographics. Problems and Prospects for the Development of Education: materials of the VI Intern. scientific conf. Online, 2015. Disponível em: $<$ https://moluch.ru/conf/ped/archive/149/7760>.Acesso em: 10 abr. 2020.

GABOVA, M. Visual Culture of Modern Society (experience of typology). Man.

Culture. Education, v. 24, n.2, p. 30-40, 2017.

GALKIN, D. Digital Culture: Horizons of Artificial Life. Tomsk: Tomsk University Press, 2013.

GALKIN, D. Technology of New Media: to the Issue of the Genesis of Digital Culture. Humanitarian Informatics, v. 2, p. 37-60, 2005.

GORBACHOVA, A. Obmen vizual'noy Informatsiyey i Korotkimi Soobshcheniyami kak Sovremennyy Vid Setevykh Kommunikatsiy. PRAXĒMA - Problemy vizual'noy semiotiki, v.1, n.3, p. 133-139, 2015.

JACOBSON, S. Transcoding the News: An investigation into multimedia journalism published on nytimes.com 2000-2008. New Media \& Society, v.14. n.5, p. 1-19, 2012. Disponível em: $<$ https://journals.sagepub.com/doi/abs/10.1177/1461444811431864>. >. Acesso em: 10 abr. 2020.

KAZARINA, T. Sovremennaya Vizual'naya Kul'tura v Kontekste Sistemnogo Podkhoda, Aktual'nyye problemy sotsiokul'turnykh issledovaniy, v.10, p. 113-120, Online, 2018. 
KINTSANS, V. Vizual'naya Kul'tura: Analiz i Puti Formirovaniya. Anais... 2-nd International Scientific and Practical Conference World Science: Topical researches of the World Science, Junho 29-30, 2016, Dubai, UAE: Proceedings, Dubai.

KITTLER, F. Optical Media. Moscou: Publishing House Logos, 2009.

KROSHNEVA, M., MALENOVA, O. Information Visualization and Infographics: a Teaching aid for Students of Publishing major. Ulyanovsk: UlSTU,2018.

KROYCHIK, L. Communicative and Functional Strategies of Modern Newspaper Texts. Media genres: History, Theory, Practice: materials of IV and V All-Russian scientific and practical conferences, 2012. p. 100-117.

LAIKOVA, Y. Infographics in the Russian media: Periodization and Development Trends. MediaScope, n. 2, Online, 2015. Disponível em: $<$ http://www.mediascope.ru/ taxonomy/term/9>. Acesso em: 10 abr. 2020.

LAIKOVA, Y. Media Infographics as a Format for Media Text in Russian Online Media, Tese de doutorado, Moscou: 2016.

LAPTEV, V. Design and Artistic Evolution of Russian Infographics (XIX - XX centuries): Origin, Formation, Development: 17.00.06 Technical aesthetics and design major: Tese de doutorado, Moscou: 2018.

LAPTEV, V. Infographics: Basic Concepts and Definitions. Nauchnotechnicheskie vedomosti of SPbSPU. Humanities and social sciences, v.184, n.4, p. 180-187, Online, 2013.

MANOVICH, L. Language of New Media. Moscou: Ad Margin Press Moscow, 2018. MANOVICH, L. The language of new media. Cambridge: The MIT Press. 2001.

MCLUHAN, M. Gutenberg Galaxy: The Making of Typographic Man. Kiev: NikaCenter, 2004.

MCLUHAN, M. Understanding Media: the Extensions of Man. Moscou: CANONPress-Ts, 2003.

MITCHELL, W. J. T. Image science: Iconology, Visual Culture, and Media Aesthetics. Chicago: University of Chicago Press, 2015.

NIKULOVA, G., Podobnikh A. Means of Visual Communication. Infographics and Metadesign. Educational Technologies and Society, n. 2. p. 369-387, Online, 2010. OSTRIKOV, S. Design and Art Modeling of Infographics: Theoretical Foundations and Principles. Tese de Doutorado, 223 p., Moscou, 2014a.

OSTRIKOV, S. Theoretical Foundations and Principles of Infographic Design: 
monograph. Moscou: FGBOU VPO Moscow State Art and Industry Academy named after S. G. Stroganova, 2014b.

SHEVCHENKO, V. Visual Content as a Trend in Modern Journalism. Electronic Scientific Journal MediaScope, v. 4. Online, 2014. Disponível em: <http://www. mediascope.ru/1654>. Acesso em: 10 abr. 2020.

SIMAKOVA, S. The Philosophical and Aesthetic Foundations of Visual Practices in Journalism. Znak: Problematic Field of Media Education. Chelyabinsk, v. 33, n. 3, p. 166-174, 2019b. DOI: 10.24411 / 2070-0695-2019-10320

SIMAKOVA, S. Infographics in the Context of Post-humanistic Trends in Journalism. Bulletin of the Voronezh State University - Voronezh, n. 3. p. 127-131, Online, 2019a.

SVITICH, A. Graphical Illustration as a Visual Component of the Content of Quality Press: author's abstract. Tese de Doutorado. Moscow, 2016.

TONKIKH, V. Russian Civilization: Society and Personality. Istoki: Voronezh, 1999.

TULUPOV, V. Forms of Filing and Genres of fine press journalism. Bulletin of Voronezh State University. Philology. Journalism, n. 1, 137-142, Online, 2015. VIRILLO, P. The Vision Machine. Nauka: São Petersburgo, 2004.

ZAGIDULLinA, M. Deus Ex Machina: The Human during the Expansion of the Mechanical and the Electronic. Novoe literaturnoe obozreniye, v. 149, n. 1, p. 428443, Online, 2018.

ZAGIDULLINA, M. Key Features of Media Aesthetics: Mental and Linguistic Transformations. Chelyabinskiy Gumanitariy, v. 35, n. 2, p. 46-52. Online, 2016.

ZETTL, H. Sight Sound Motion: Applied Media Aesthetics. 6. ed. Boston: Wadsworth Cengage Learning, 2011.

ZITZER, V. Infographics is not Just Design. Information systems and technologies in education, science and business (ISIT-2014): materials of the All-Russian Youth Scientific and Practical School. Kemerovo: 2014.

\section{Acknowledgments}

The research was carried out with funds from the grant of the Russian Science Foundation, project No. 18-18-00007 